\title{
Sustainability Aspects of the Wheat Sector
}

\author{
István Kiss \\ University of Debrecen, Debrecen, Hungary \\ Szilvia Bencze \\ BEN-KG Lp., Csömör, Hungary
}

\begin{abstract}
In the frame of the present study, we examined the wheat sector with respect to economic and social sustainability. Accordingly, two research questions were formulated: (1) Is wheat production sustainable in economic terms? and (2) Is wheat production sustainable in social terms? Our view is that the content of sustainability can be defined on a case-by-case basis, and in our case, wheat production provides this content. To answer the research questions, we collected statistical data on the production area, average yield, production volume, selling price, consumption of wheat, and evaluated the tendencies prevalent in the sector. We suppose that in social terms, sustainability means maintaining consumption at least at a constant level, knowing that this sector produces considerable share of the direct and indirect food raw materials. A chief dilemma is that world population is continuously growing, although the size of the cultivated area in the wheat sector has not indicated significant changes over the past few decades. Unless increasing the yields, severe decrease may occur in the per capita production of wheat in the long run. In this case, the current consumption level will not be sustainable in the medium run. In addition, in the long run, it may even have influence on the consumption level of other commodities.
\end{abstract}

Keywords: wheat sector, sustainability, competitiveness, production, consumption level

\section{Introduction}

Sustainability is based on three interrelated pillars: social, economic, and environmental. In the frame of the present paper, we examine the social and economic aspect of sustainability concerning wheat production. Environmental sustainability is undoubtedly vital regarding the future of the human society, however due to its complexity we do not examine this aspect in the frame of this study. Today's important issue is how the demand for continuous development of the human world can be satisfied in a sustainable way. It is a question of utmost importance whether the human society will be able to deliver sufficient quality and quantity of food to the growing world population. Regarding the social dimension, it must be highlighted that many people are starving and dying of hunger in the developing world, while many people suffer from illnesses caused by obesity in the developed world. The question may be raised whether the differences and the social gap between the developed and the developing world can be mitigated or on the contrary, the crisis of society will further expand.

István Kiss, Agricultural Economist, Ph.D. candidate, Faculty of Applied Economics, Rural Development, University of Debrecen.

Szilvia Bencze, Agricultural Economist, BEN-KG Lp..

Correspondence concerning this article should be addressed to István Kiss, Hejöpapi, Petőfi utca 16. 3594. Hungary. E-mail: kissistvan86@gmail.com; btitia85@gmail.com. 
The plant production area in the world is around 1,500 million hectares. Figure 1 depicts the sowing structure in 2009 on a global scale. The figure properly shows that the growers produce cereals on the $48 \%$ of the sowing area in the world, and that maize, rice, and wheat are the most significant crops within cereals. The rate of these three plants together is $36 \%$ within the entire sowing area, which is equal to 546 million hectares. Wheat has the largest sowing area within cereals, to be precise it is 225.4 million hectares and it occupies $15 \%$ of the area being under plant production in the world. Proportions of the three main cereals can be deemed steady in the examined years. According to us, significant changes are not expected in the sowing structure in the future.

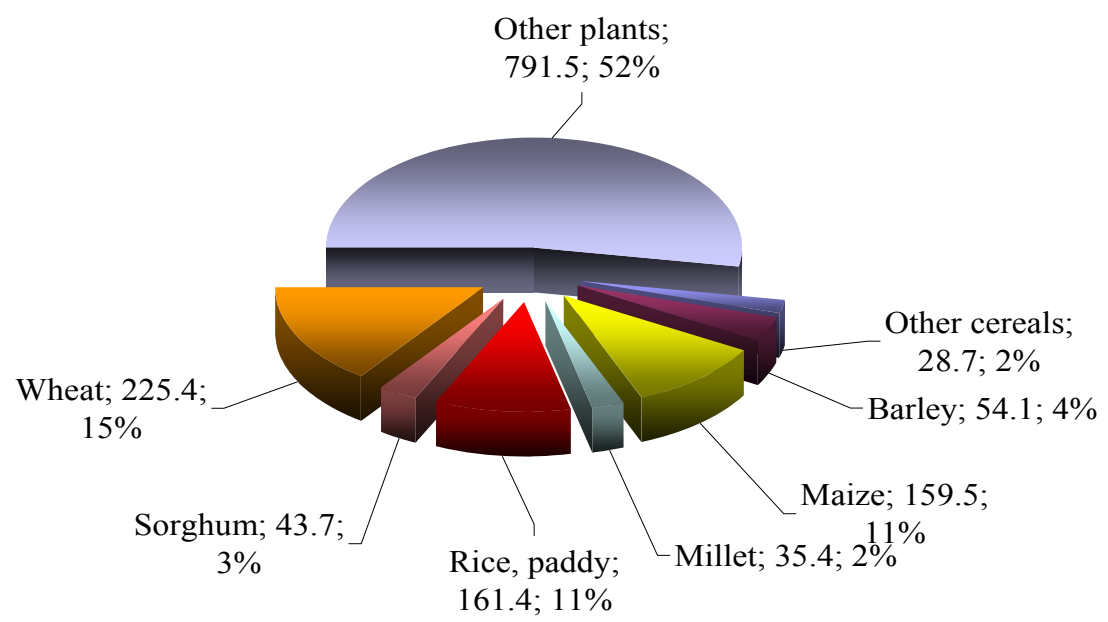

Figure 1. Division of the sowing area in the world in 2009 (in million hectares and percentage). Source: FAO, 2011.

As mentioned above, the proportion of rice and maize is also significant beside wheat. The share of the other cereals is under 5\% within the entire sowing area of the world.

\section{Sustainability of the Wheat Sector}

\section{Social Dimension}

Table 1 shows the development of world's wheat production from 1990 to 2009 . In our view, social sustainability requires the current consumption level to be maintained. One can see at first sight that in the last 20 years there was no significant change in the size of the sowing area of wheat which fluctuated between 208 and 231 million hectares. However, there was a significant increase in the total production quantity of wheat which is explained by increasing average yields. Since world population continuously increases, the size of per capita production area decreases worldwide. However, per capita production quantity of wheat does not decrease significantly again due to the increasing yields. In 2009, 2.56 tons of wheat was produced on one hectare, which value increased to 3.02 tons by 2009. In addition, according to some projections the potential yield per hectare might reach the level of 3.5 tons by 2025. Fulfilling this projection is essential if the world population is to be supplied with sufficient amount of food. In this respect it is good news that this yield might be achieved thanks to the genetic potentials of the crop.

Table 1 shows that per capita production was the highest in 1990, which level was followed by stagnating values due to the fact that the yields have increased slightly in the past 20 years even if per capita arable land decreased and is projected to continuously decrease in the coming decades according to a 2011 FAO study (see Figure 2). The question is how long the current level of consumption can be maintained by increasing the yields! 
We believe that the sector can grow, considering that the average yield was about three tons/ha in the world in 2009 , and this plant has a much larger genetic potential. Nonetheless each country can exploit it differently due to the different climatic conditions. In Hungary an average yield of six tons per hectare can be considered extremely good, whereas in the United Kingdom even an average yield of 10-12 tons per hectare is not rare. Potori and Vöneki (2006) emphasised that both the USA and Canada run extensive wheat production. In the USA the average yield of wheat is three tons per hectare, many hundred types of wheat are produced and wheat is only the fourth most important crop, still the US' wheat self-sufficiency level is $180 \%$. The self-sufficiency level of Canada is even higher than in the US': Canada having an average yield level of 1.8-2.6 tons per hectare has a self-sufficiency level of $280 \%-300 \%$ (Potori \& Vöneki, 2006, as cited in Kató, 2009). These high levels of self-sufficiency might well mean that there will be no need to intensify wheat production in North America.

Table 1

Wheat Production Between 1990 and 2009

\begin{tabular}{llllll}
\hline Years & $\begin{array}{l}\text { Area harvested } \\
\text { (million hectares) }\end{array}$ & $\begin{array}{l}\text { Production } \\
\text { (million tonnes) }\end{array}$ & $\begin{array}{l}\text { Average yield } \\
\text { (t/ha) }\end{array}$ & $\begin{array}{l}\text { Area/capita } \\
\text { (hectare/capita) }\end{array}$ & $\begin{array}{l}\text { Production/capita } \\
\text { (kg/capita/year) }\end{array}$ \\
\hline 1990 & 231 & 592 & 2.56 & 0.044 & 111.98 \\
1991 & 223 & 544 & 2.45 & 0.042 & 101.80 \\
1992 & 223 & 565 & 2.54 & 0.041 & 103.59 \\
1993 & 223 & 565 & 2.53 & 0.04 & 101.91 \\
1994 & 215 & 527 & 2.45 & 0.038 & 93.78 \\
1995 & 216 & 543 & 2.51 & 0.038 & 95.18 \\
1996 & 227 & 585 & 2.58 & 0.039 & 101.23 \\
1997 & 226 & 613 & 2.71 & 0.039 & 104.68 \\
1998 & 220 & 593 & 2.70 & 0.037 & 99.97 \\
1999 & 213 & 587 & 2.75 & 0.036 & 97.71 \\
2000 & 215 & 585 & 2.72 & 0.035 & 96.17 \\
2001 & 215 & 589 & 2.75 & 0.035 & 95.65 \\
2002 & 214 & 574 & 2.69 & 0.034 & 92.07 \\
2003 & 208 & 560 & 2.70 & 0.033 & 88.65 \\
2004 & 217 & 632 & 2.92 & 0.034 & 98.95 \\
2005 & 220 & 626 & 2.85 & 0.034 & 96.88 \\
2006 & 212 & 602 & 2.85 & 0.032 & 92.09 \\
2007 & 217 & 612 & 2.83 & 0.033 & 92.48 \\
2008 & 223 & 683 & 3.07 & 0.033 & 101.98 \\
2009 & 225 & 681 & 3.02 & 0.033 & 100.62 \\
\hline
\end{tabular}

Note. Source: FAO, 2011.

However, the ever growing world population will certainly make it necessary to increase wheat production, especially if meet consumption grows in the developing countries, too. The reason for the latter is that to produce more meat more fodder is needed, and as a consequence wheat self-sufficiency level of the countries will go under changes. If the human society once reaches such a high level of civilization that ensuring the well-being of few people does not endanger the life of others, then intensification of wheat production and hence establishing food security become an utmost important issue for everybody. And even if the current level of consumption is theoretically sustainable, there is another serious problem that we have to face: Today people are dying of hunger in the world even apart from this problem. If we go beyond looking at the average consumption level on the global scale, we will face immense differences among the level of consumption in the 
different regions of the globe. There is a well known howling discrepancy between the developed and the developing world: namely, there is excess and at the same time wasting of food in the so-called modern societies, and on the other hand lack or undersupply of food in the poorer countries. People are suffering from overweight and its consequent illnesses in the developed world and on the other part of the world people are suffering from lack of food, from undernourishment and its consequent illnesses. Table 2 presents the total wheat consumption by regions and it also illustrates the per capita wheat consumption in the regions. To get a broader overview of food consumption on a global scale, we demonstrate also the relative meat consumption and the regions' share within the world population in the same table. Per capita wheat consumption is the highest in Europe, where its value is $108 \mathrm{~kg} /$ capita/year (FAO, 2011). Wheat consumption of Europe is $18 \%$ of the world's total consumption of wheat as food. Asia represents the biggest rate (58\%) in the world's total consumption of wheat as food. However, wheat consumption per capita per year is $64 \mathrm{~kg}$ in the biggest continent (FAO, 2011). This amount is much lower than the consumption in Europe, since it is the rice that plays much bigger role in their diet. The wheat consumption is $63 \mathrm{~kg} /$ capita/year in the Americas whose share is $13 \%$ of the world's consumption. In Oceania's consumption is $71 \mathrm{~kg} /$ capita/year, and its total consumption can be considered as a negligible part within the world's wheat consumption (FAO, 2011).

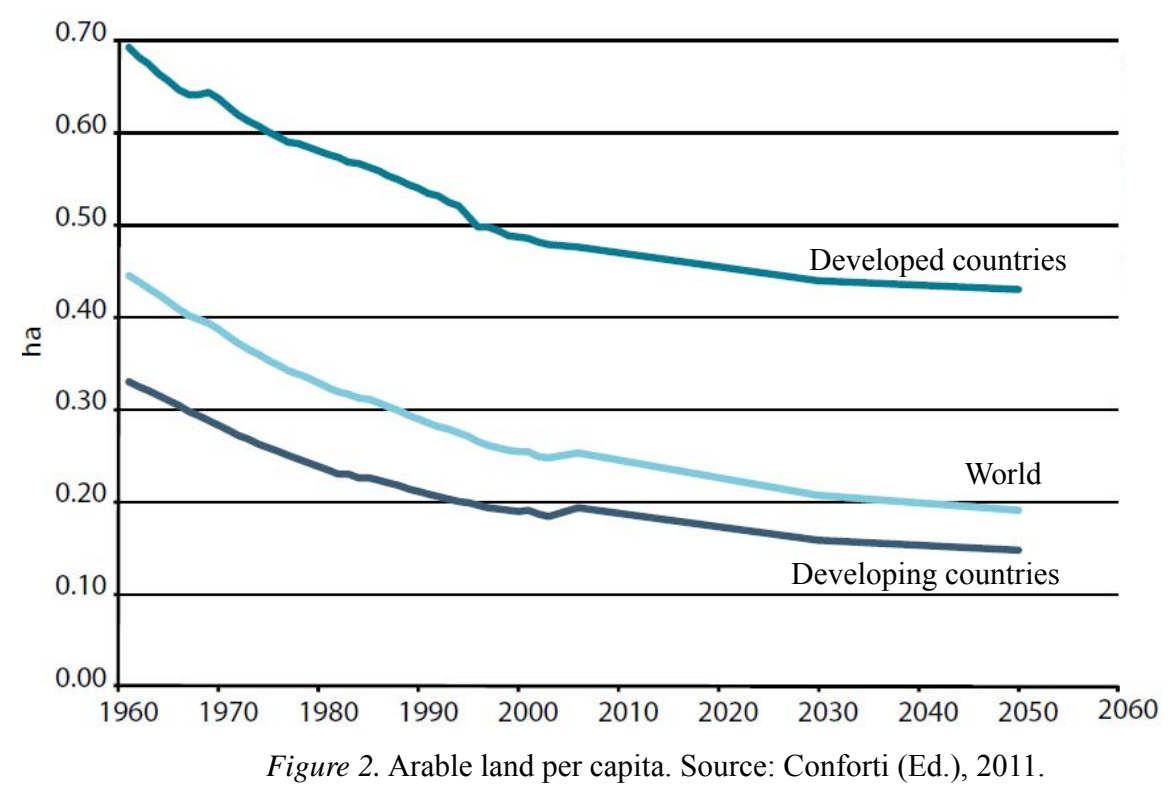

Table 2

Global Wheat and Meat Consumption by Region in 2007

\begin{tabular}{lllllc}
\hline Regions & $\begin{array}{l}\text { Wheat consumption } \\
\text { (kg/capita/year) }\end{array}$ & $\begin{array}{l}\text { Wheat consumption } \\
\text { (million tonnes) }\end{array}$ & $\begin{array}{l}\text { Share (\%) } \\
\text { world wheat } \\
\text { consumption }\end{array}$ & $\begin{array}{l}\text { Share (\%) } \\
\text { world meat supply }(t)\end{array}$ & $\begin{array}{l}\text { Share (\%) total world } \\
\text { population }\end{array}$ \\
\hline Asia & 63.62 & 252.16 & 58 & 42 & 60 \\
Europe & 108.24 & 79.08 & 18 & 21 & 11 \\
America & 63.16 & 57.22 & 13 & 26 & 11 \\
Africa & 45.58 & 43.48 & 10 & 6 & 15 \\
Oceania & 70.66 & 1.94 & 0.45 & 1 & 1 \\
World & 65.92 & 433.88 & 100 & 100 & 100 \\
\hline
\end{tabular}

Note. Source: FAO, UN 2011. 


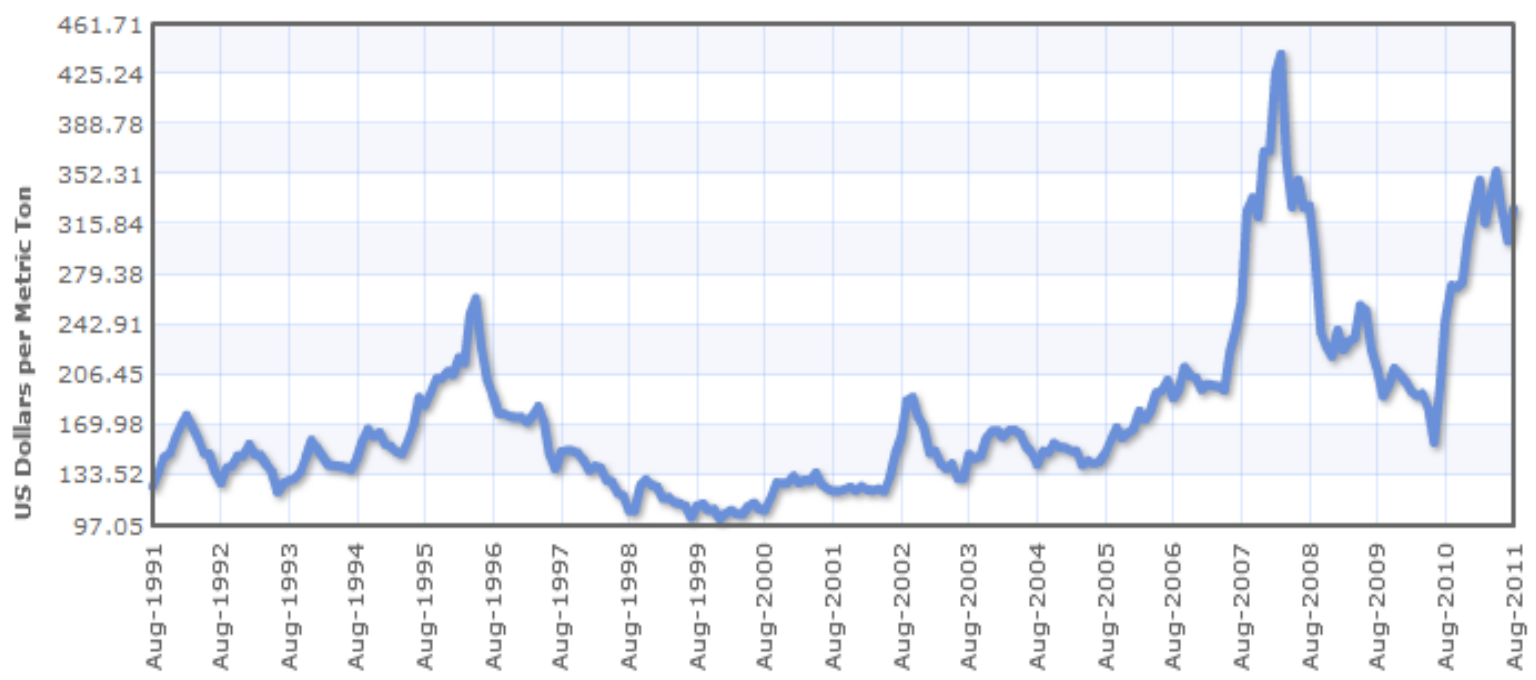

Figure 3. Price of wheat, 1991-2011. Source: Index Mundi, 2011.

Africa's wheat consumption per capita per year is low, exactly $46 \mathrm{~kg} / \mathrm{capita} /$ year. Africa's rate is only $10 \%$ of the world's total wheat consumption, but the meat consumption here is even lower (6\%), especially taking into account its share within the world population (15\%). In 2007, 434 million tons of wheat was used for culinary purposes in the world and the average wheat consumption of the world population was 65.9 $\mathrm{kg} / \mathrm{capita} /$ year $(\mathrm{FAO}, 2011)$. One can see that the share of total wheat consumption by region is more or less in line with the regions' share of world population, although it is not true for meat consumption that varies with greater amplitude in favour of the developed regions. Nonetheless, per capita consumption of wheat shows significant differences between developed and developing regions. What about these regions and nations lagging behind? Can the social gap be maintained between the Third World and the developed world? In our view no, because it is only a matter of time and the ever deepening social tensions can cause the downfall of the current system. We have no illusions about the possibility of a system collapse, since it will be very difficult to stop the hungry people. In addition, nobody can consider armed counter-movement a sensible option for the developed world to defend itself. From social point of view, the current consumption level of grains is not sustainable unless increasing the yields. To increase the yields, it is essential to ensure the maintenance of profitability for the producers. Better yields require higher level of inputs, which entails higher costs, but from economic point of view, an unprofitable sector is not sustainable in the long run. At present, the price of wheat is far higher than before, but production costs have also increased. High prices are integrated in food prices as well, which makes it also difficult to preserve the sustainability of the consumption levels. Figure 3 reflects the average monthly price of wheat (U.S. number $1 \mathrm{HRW}$, fob Gulf of Mexico in US Dollars per Metric Ton (units)) between 1991 and 2011. However, there is another working solution for the problem that should be rather applied in parallel with increasing the yields of wheat production as described above. It is not enough only to emphasize the sustainability of the current global consumption level of food and of wheat at the same time, but there should be a sober and sensible reorganization of food systems, production and supply. Food aid programs only prolong the suffering of poor nations, and they do not solve the reason of the food shortage. The people of these countries will always need food aid, if they only get limited food portions occasionally or even regularly, which is unambiguously an unsustainable practice. Food aid programs do not promote them to become self-sufficient in food. The immense money spent on food aid programs should rather be spent on 
education and farming training programs in the developing countries and on the establishment of independent food systems for the millions of hungry. Fertile soil and/or fish-rich water is given in the vast majority of these countries, but many times huge multinational companies, hotel chains or local petty rulers occupy them, although long ago these lands belonged to the local people, and the problem of food shortage and hunger was unknown (Korten, 2001).

Creating viable and possibly competitive food production systems - first of all grain production as primary source of food - in these regions would ease the pressure on the agriculture of the developed world that tries to supply food to the entire world population.

The 2008 World Development Report published by the World Bank also found that for the poorest people, GDP growth originating in agriculture is about four times more effective in raising incomes of extremely poor people than GDP growth originating outside the sector. This way both the distribution of wealth and the current extremely variable consumption levels could be balanced, and it would be much easier to sustain an acceptable level of wheat consumption as well. According to a FAO study, the growth of the world population will slow down, which could ease the pressure on agriculture to provide food. According to this study, by 2050 total world population will reach nine billion. At the same time the study is also optimistic about the future world food supply, and it forecasts that by 2050 the number of undernourished will decrease to 290 million from 810 million in 2000, and the portion of well-fed (i.e., not classified as undernourished) from $83 \%$ to $96 \%$. Nevertheless, the study also emphasizes the importance of local production to meet the growing food demand in developing countries (Conforti (Ed.), 2011). Social sustainability of the grain sector is a highly important issue. People are dying of hunger nowadays, and the modern day people perceive it indifferently. Responsibility of the developed world is not a question, since many times we staff our garbage bins with food due to our disproportionate and excessive consumer and purchasing habits. Nowadays' consumer society serves only the interests of the giant profit-oriented corporations. It does not promote in any form the emergence and operation of a more human economic system. Indeed, the well-being of nowadays' modern societies costs many human lives day-by-day.

People should not be so easily influenced by the wishes and suggestions of big corporations. Modern day people must refuse and defeat the excessive consumption habits generated by the marketing tools. We must take social responsibility when doing shopping. It may seem to be a small step, but firstly we should try to buy as much food as we really need and certainly able to consume. It is extremely important to be aware of our own contribution to social sustainability in our ordinary, day-to-day life.

\section{Economic Dimension}

If we talk about economic sustainability, we mean that a given sector does not shrink, and it can maintain its economic performance. Our economic world is profit-driven, so it is an important question whether will so much income be generated in the sector that farmers will continue producing in the future as well? We compared the wheat sowing area with other important crops' sowing area.

Figure 4 demonstrates the production quantities of the main crops between 1990 and 2009. The sowing area of the wheat stagnated in the investigation period. However, the sowing area of rape, maize, sunflower and rice increased slowly but continuously. Increase in the sowing area of maize, sunflower and rape is partly due to their production as energy crops and the higher profit arising from it. The wheat sowing area has not decreased despite the increase in the sowing area of these crops. 


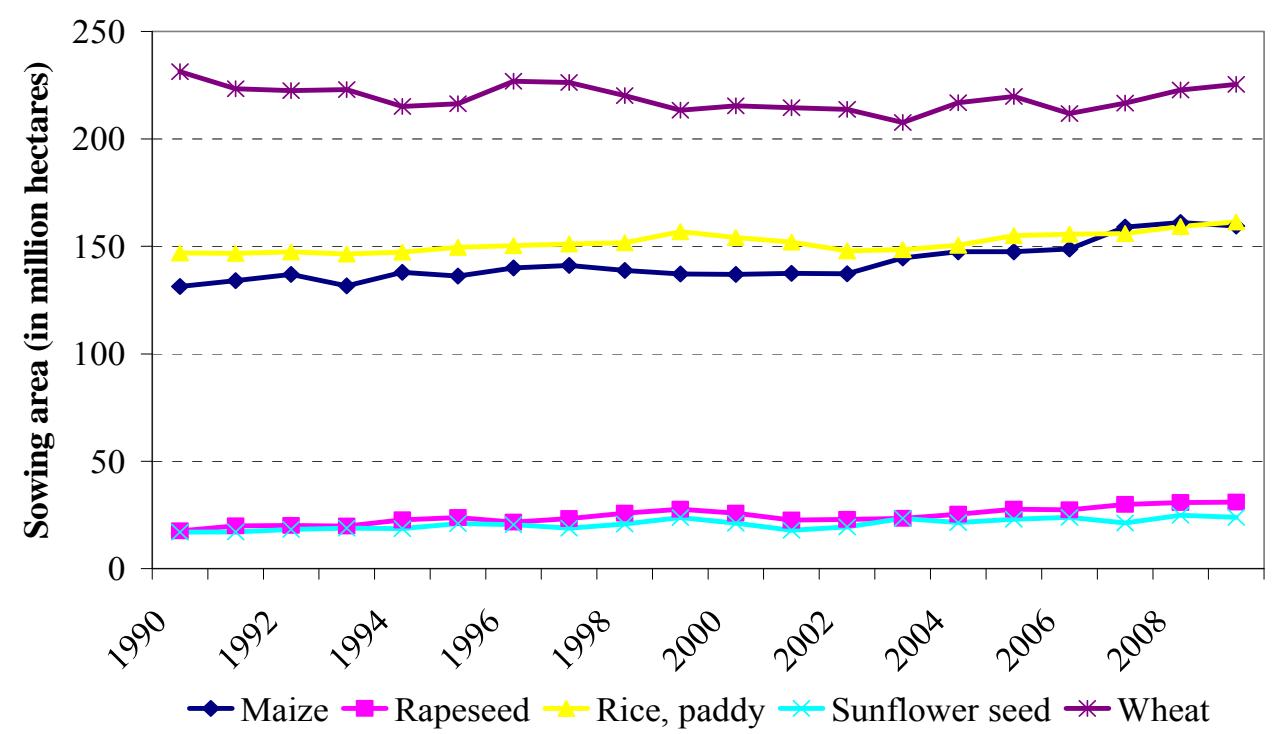

Figure 4. The evaluation of the major crops' and other plants sowing area between 1990 and 2009. Source: FAO, 2011.

In our view, the higher profitability of other crops does not reduce the global economic importance of the wheat sector in the short run.

Taking into account the price of wheat in 2010 and 2011, it can be stated that currently wheat production is competitive in comparison with other plant production sectors. Therefore, in this respect economic sustainability of the sector is unquestionable, because looking at the current prices wheat production is profitable. On the other hand high prices endanger sustainability from social point of view, i.e., the maintenance of the level of consumption. High prices of food raw materials — in our case of wheat —entails high food prices worldwide. In the developing world it was difficult to supply enough food even before. Due to the high prices the gap between the developed and the developing world will further increase. It is possible that hunger riots will dangerously threaten the cohesion of the current economic-social-political system. High prices can be explained by stock exchange transactions up to a certain extent, since at present the shortage of food raw materials on a global scale is not so significant to induce such high price levels. The aforementioned FAO study underpins this statement, but with caution. Investment funds started to enter commodity markets in the early 2000s, and by 2010 the level of such investments reached roughly USD350 billion. One reason why speculative investments increased the prices of agricultural commodities is that these investments are based on the basis of past performance which is often in contrast to actual market and real economy processes and trends. Furthermore, these hedge and investment funds are far too large in comparison with commodity markets, consequently their potential influence on commodity prices might be well out of proportion (Conforti (Ed.), 2011). Soros (2008) also called commodity index buying "intellectually unsound, potentially destabilizing and distinctly harmful in its economic consequences". However, the FAO study tries to draw a cautious conclusion, because there are some quite influential views on the side of speculative trading. For example, two studies of the International Monetary Fund (IMF, 2006, 2008) argued that there is no direct price boosting effect of speculation.

Growing world population and high food prices will cause the per capita consumption level of wheat to decrease in the developing world. Nevertheless, even with increasing yields and decreasing prices it would be not easy to cut back starvation, because people in developing countries have low-level or no income at all. 
Without income their purchasing power converges to zero.

Aid programmes aiming at making up for the lack of income are not the proper solution to the problem. It is similar to the case when one wants to cure an illness. The solution is not to treat the symptoms, but to eliminate, or at least to soften the original cause. In our case, the original cause is the economic underdevelopment of developing countries, which entails that their human capital is also underdeveloped, since the educational system in the third world is by far underdeveloped in comparison with developed countries. Consequently, they do not even have the knowledge to establish their economic independence in the current economic system.

\section{Conclusion}

In the present paper, we analysed statistical data on the world wheat production. We observed the sustainability of the sector from social and economic point of view. On the basis of our analysis, we draw the following conclusions:

(1) Overall, in our view wheat production can be sustainable in the short run. In social terms the per capita wheat production can be sustainable despite the growing world population partly due to the possible increase in specific yields and partly due to the possible establishment of viable, competitive and efficient farming systems in the developing countries.

(2) Another question is how long this situation can be maintained with the complete utilization of the current genetic potential in case the population growth does not stop. According to the predictions, the population growth will reach its peak point by the year of 2050, when presumably nine billion people will live on the Earth.

(3) Regarding the economic dimension of sustainability, it was found that although there was a slight increase in the sowing area of other important crops, this increase was not a detriment to the sowing area of wheat. Economic sustainability of the sector is beyond doubt due to the current high price of wheat. The high price of food partly due to the high wheat prices is a natural phenomenon and it refers to the social dimension again. It is a question whether these prices are sustainable nowadays when there are serious social differences in the world. In our view, it can lead to serious social tensions in those developing countries where the shortage of food is a decisive problem, because high food prices will further deepen the social problems.

Nevertheless, we think that responsible and sensible decision makers could overcome this latter challenge by promoting the setting-up of viable, competitive and efficient farming systems in the Third World. The question is whether there are/will be such decision makers. Due to the limitations of the present study, we tried to focus on the essence of the problem, and we tried to provide a comprehensive overview of the wheat sector. Evidently, the topic requires further and deeper analyses.

\section{References}

Conforti, P. (Ed.) (2011). Looking ahead in world food and agriculture: Perspectives to 2050. FAO. Agricultural Development Economics Division. Economic and Social Development Department. 2011. IMF. 2006. World Economic Outlook 2006. Washington, D.C..

FAO. (2011). Food and Agricultural Organization of the United Nations (FAO) database.

IMF. (2008). World economic outlook 2008. Washington, D.C..

Index Mundi. (2011). Wheat daily price. Retrieved September 22, 2011, from $\mathrm{http}: / /$ www.indexmundi.com/commodities/?commodity=wheat\&months $=240$

Kató, N. (2009). A magyar gabonaágazat—különös tekintettel a búza-és kukorica ágazatra—folyamatai hazánk Európai Unióhoz 
történt csatlakozását követően (Trends of the Hungarian grain sector after accessing the European Union, with focus on the wheat and the maize sector) (Doktori értekezés (Ph.D. dissertation), Szent István Egyetem (Szent István University)).

Korten, D. C. (2001). When corporations rule the world. Berrett-Koehler Publishers. Inc..

Potori, N., \& Vöneki, É. (2006). Néhány fontosabb mezögazdasági termék termelési költségének nemzetközi összehasonlítása (International comparison of the production costs of the main agricultural products). Agrárgazdasági Információk (News on Agricultural Economics), 1, 2-19.

Soros, G. (2008, June 3). Testimony before the US Senate Commerce Committee Oversight: Hearing on FTC advanced rulemaking on oil market manipulation. Washington, D.C.. Retrieved September 22, 2011, from http://www.georgesoros.com/files/sorosfinaltestimony.pdf

United Nations (UN) database. (2011). Retrieved September 22, 2011, from http://www.esa.un.org/unpd/wpp/unpp/panel_population.htm

World Bank. (2008). World development report 2008: Agriculture for development. Washington, D.C.: World Bank. 